\title{
Norman Douglas Pailthorpe
}

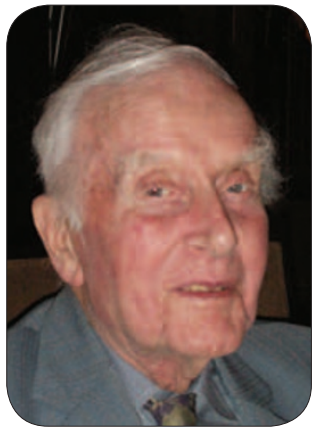

Norman Pailthorpe died on 30 January 2007, aged 92 years, after a short illness. He qualified from Birmingham Dental School in 1935 and after a few locums accepted a partnership in general dental practice in Loughborough .

During the war he enlisted in the Army Dental Corps and spent four years in the Middle East which included postings to Egypt, Eritrea, Syria, Haifa and Hadera. He returned to practice in Loughborough after the war and, in 1946, married Gwen, to whom he was happily married for 53 years.

His professional attitude and dedication towards his patients and colleagues led him to become involved in the LDC as Secretary, Treasurer and then Chairman, a founder member of the Sheffield and District Orthodontic Study Circle and Chairman (1966-8), Secretary of his local BDA Section, Chairman of East Midlands Branch, Chairman (1965-6) and Treasurer (1983-92) of the 250 Club and to sit on the national selection panel when the first Area Dental Officers were appointed. His contribution to dentistry, and in particular

\section{He lived a long, full and happy life.}

the BDA, was recognised when he was awarded life membership in 1974. He, with his partner John Coe, will also be remembered as inventors of the Paco bath for the curing of dental acrylic.

In 1972 Norman retired due to ill health and moved to Anglesey, but he couldn't remain idle long. He initially took up breeding rabbits commercially and quickly became Chairman of the Commercial Rabbit Breeders Association. However his love of dentistry continued and he became an SDO doing domiciliary denture work for the local CDS until Gwen's health deteriorated.

Norman and Gwen had three children, Sheila, Charles and Helen, and five grandchildren. They moved to Reading in 1995 to be near Charles and his wife, Helen. Sadly Gwen passed away in 2000 but Norman remained independent until shortly before his death, even working as a volunteer at the Royal Berkshire Hospital until last summer. He loved travelling and his last trip was aged 91 to spend Christmas with his daughter, and her family! He lived a long, full and happy life and will be missed by his family and friends.

J. H. Pailthorpe

\section{Kenneth Cranston}

Kenneth Cranston, who died on 8 January 2007, aged 89, once decided to spend six months playing first class cricket, and performed so well that within three months he was playing for England, and within nine months was captain of his country.

Born in Aigburth, Liverpool on 20 October 1917, Ken attended Liverpool College where he excelled at sport, particularly cricket and hockey. He once scored 289 in three hours as a schoolboy playing for Liverpool Pilgrims at Eastbourne.

After leaving school he became an undergraduate at the Dental School, Liverpool University. Continuing to play cricket, he scored a century for Lancashire second team against Yorkshire. Harry Makepeace, the coach at Old Trafford and a man not given to exaggeration, rated Cranston as the best talent he ever taught.

Graduating BDS in 1940, Ken's sporting career was, along with many others, interrupted during his potentially best years by the war when he served as a dental officer in the Royal Navy.

Afterwards, Ken decided in 1947 to take a sabbatical from dentistry and play cricket for Lancashire. Following a reorganisation at Old Trafford he was immediately appointed county captain and had a brilliant season culminating in being selected for England in the third Test Match against South Africa. He demolished South Africa at Headingly with his fast medium bowling taking four wickets in six balls. This secured his selection as Vice Captain for the MCC tour to West Indies that winter under the captaincy of 'Gubby' Allen. Allen was injured and Cranston captained England in the first test match drawn. His personal highlight was taking 4 for 79 in the fourth test at Georgetown, including the wickets of Walcott and Weeks who were becoming world renowned.

\section{Ken Cranston is the only dentist to captain England and the MCC.}

Cranston continued to captain Lancashire in 1948, scoring 1,228 runs and taking 83 wickets. He was perhaps unfortunate to be recalled to the England team to play the all powerful Australians when England lost by seven wickets. Ken's recounted memory of the game was the Australian captain, Don Bradman, who had poor teeth, anxiously seeking professional advice from Cranston in the dressing room!

Having retired from regular first class cricket at the end of 1948 he, as promised, returned to dentistry, joining his father's practice in Aigburth where he practised until retirement in 1990. During the 1950s he played club cricket and county hockey for Lancashire, and was elected a member of Styx Hockey Club. During that time he played occasional matches for Lancashire, once scoring a memorable 156, his highest first class score, against the county champions Yorkshire at the Scarborough Festival.

Ken Cranston was elected President of Lancashire County Cricket Club in 1993-4.

He married firstly Mary Harrison in 1942 (dissolved in 1964) and they had a son and a daughter, and secondly Joanne Legg in 1964 with whom he had a son.

While several dentists have experienced playing first class cricket, Ken Cranston is the only dentist to captain England and the MCC.

S. Robson 